\title{
Depth profile exploration of enzyme activity and culturable microbial community from the oxygen-starved soil of Sundarban mangrove forest, India
}

\author{
Subhajit Das ${ }^{1}$, Tarun kumar Sarkar ${ }^{2}$, Minati De $^{3}$, Dipnarayan Ganguly ${ }^{1}$, Tusher kanti Maiti ${ }^{4}$, \\ Abhishek Mukherjee ${ }^{1}$, Tapan kumar Jana ${ }^{1}$, Tarun Kumar De ${ }^{1^{*}}$ \\ ${ }^{1}$ Department of Marine Science, Calcutta University, Calcutta, India; \\ *Corresponding Author: tarunde@gmail.com; subhajit 310@yahoo.com \\ ${ }^{2}$ Department of Community Medicine, North Bengal Medical College, Darjeeling, India; \\ ${ }^{3}$ Maniktala Siksha Bhavan, Calcutta, India; \\ ${ }^{4}$ Microbiology Laboratory, Department of Botany, Burdwan University, Burdwan, India.
}

Received 23 August 2011; revised 26 September 2011; accepted 16 October 2011.

\begin{abstract}
Populations of culturable microbes and activeties of dehydrogenase $\& \beta$-D glucosidase were found maximum in surface soil and decreased with increase in depth in Sundarban mangrove environment. The maximum $\left(13.529 \times 10^{6}\right.$ C.F.U $\mathrm{g}^{-1}$ dry weight of soil) and minimum (11.547 $\times 10^{6}$ C.F.U $\mathrm{g}^{-1}$ dry weight of soil) total microbial populations in surface soil were recorded during post-monsoon and monsoon respectively. At 60 cm depth, the minimum $\left(6.396 \times 10^{6}\right.$ C.F.U g ${ }^{-1}$ dry weight of soil) and maximum (8.003 $\times 10^{6}$ C.F.U $\mathrm{g}^{-1}$ dry weight of soil) numbers of total microbial populations were observed during monsoon and post-monsoon respectively. A decreasing trend of total microbial load, enzyme activities and nutrient status with organic carbon were found with increase in depth throughout the year. Present study revealed the relationship among depth integrated variations of physico-chemical components (viz. soil temperature, $\mathrm{pH}$, moisture, organic-C, Nitrate-Nitrogen, and available-P) and microbial populations as well as activity of dehydrogenase and $\beta$-D glucosidase enzymes.
\end{abstract}

Keywords: Sundarban; Mangrove Sediment; Enzyme Activities; Depth; Microbial Populations

\section{INTRODUCTION}

The distribution of microbial activities in estuarine systems is clearly complex and variable. Much research remains to be done in order to define the distributions of microbial activities and the major factors involved in controlling these distributions in estuaries. Mangroves are highly productive marine ecosystem where bacteria actively participate in bio-mineralization and biotransformation of minerals. [1]. Leaves and wood provided by mangrove plants to the sediment are degraded primarily by large variety of microbes and their active participation in the heterotrophic food chain [2-4]. Major products of general recycling of organic matter are detritus which is rich in enzymes and proteins and contains large microbial populations [5]. Bacteria are the major participants in the Carbon, Sulphur, Nitrogen and Phosphorrous cycles in mangrove forest [6,7]. Bacterial activities are responsible for most of the carbon recycling in mangrove sediment under both in oxic and anoxic condition. Sulfate reduction, methane production, and denitrification are the important processes for the terminal electron removal during decomposition of organic matter in anoxic environment. It has been studied that $\mathrm{N}_{2}$ fixation by heterotrophic bacteria are generally regulated by specific environmental factors like $\mathrm{O}_{2}$, combined $\mathrm{N}_{2}$ and the availability of carbon source for energy requirement [8]. Aerobic, autotrophic nitrifiers (nitrifying bacteria) oxidize $\mathrm{NH}_{3}$ to $\mathrm{NO}_{2}^{-}$and $\mathrm{NO}_{3}^{-}$, with molecular oxygen as electron acceptor. Nitrite and nitrate are reduced to gaseous di-nitrogen by heterotrophic denitrifying bacteria which use $\mathrm{NO}_{\mathrm{x}}$ instead of oxygen as electron acceptor $[9,10]$. These estimations of enzyme activities and $\mathrm{CO}_{2}$ emission provide an index of microbial dynamics. These estimations also provide an insight into the rates of organic matter breakdown and mineralization. Seasonal variation in soil enzyme activity is biologically important because they, along with the changes in the 
amount and condition of the substrate upon which they act, are indicative of the changes in rate of soil processes. Dehydrogenase activity plays an essential role in the initial stages of oxidation of soil organic matter. It depends more upon the metabolic state of the microbial population than the activity of free enzymes available in the soil. Urease and Phosphatase act as intermediary enzymes in the transformation of organic Nitrogen and Phosphorous into inorganic forms [11]. A number of studies in soil enzyme activity with physico-chemical parameters and biological distinctiveness of soils is not implicated. The purpose of the present study was to look into seasonal and depth wise variations in microbial population, interaction with physico-chemical features and the activities of the enzymes from the oxygen-starved soil of the Sundarban Mangrove Forest, India.

\section{METHODS AND MATERIALS}

\subsection{Study Area}

The Sundarban Mangrove forest is located geographically in between $21^{\circ} 31^{\prime} \mathrm{N}$ and $22^{\circ} 30^{\prime} \mathrm{N}$ and longitude $88^{\circ} 10^{\prime} \mathrm{E}$ and $89^{\circ} 51^{\prime} \mathrm{E}$ along the North East coast of Bay of Bengal, India. This mangrove forest is a part of the estuarine system of the River Ganges, NE coast of Bay of Bengal (Figure 1), which covers $9630 \mathrm{~km}^{2}$. Several numbers of discrete islands constitute Sundarbans. The climate in the region is characterized by the southwest monsoon (June-September), northeast monsoon or postmonsoon (October-January), and pre-monsoon (FebruaryMay); $70 \%$ - $80 \%$ of annual rainfall occurs during the summer monsoon (southwest monsoon), The tide in this estuarine complex is semidiurnal in nature with spring tide ranging between $4.27 \mathrm{~m}$ and $4.75 \mathrm{~m}$ and neap tide range between $1.83 \mathrm{~m}$ and $2.83 \mathrm{~m}$. It is a unique bioclimatic zone in between the land and ocean boundaries of the Bay of Bengal and the largest delta on the globe. The deltaic terrain of Sundarban Biosphere Reserve comprises mainly saline alluvial soil consisting of clay, silt, fine and coarse sand particles.

\subsection{Sample Collection}

Soil samples were collected aseptically using a handheld stainless steel core sampler $(3.2 \mathrm{~cm}$ diameter, 100 $\mathrm{cm}$ long) from six different depth i.e. 1) $0-10 \mathrm{~cm}, 2) 10$ - $20 \mathrm{~cm}, 3) 20$ - $30 \mathrm{~cm}, 4) 30-40 \mathrm{~cm}, 5) 40-50 \mathrm{~cm} \mathrm{\&} \mathrm{6)}$ $50-60 \mathrm{~cm}$ ) at five different sites in Sundarban, covering different seasons. Three replicates from each site were analyzed for five sites at different depths. The result represents the average value at each depth.

\subsection{Quantification of Bacteria}

Quantification of Bacteria: Sediment samples were

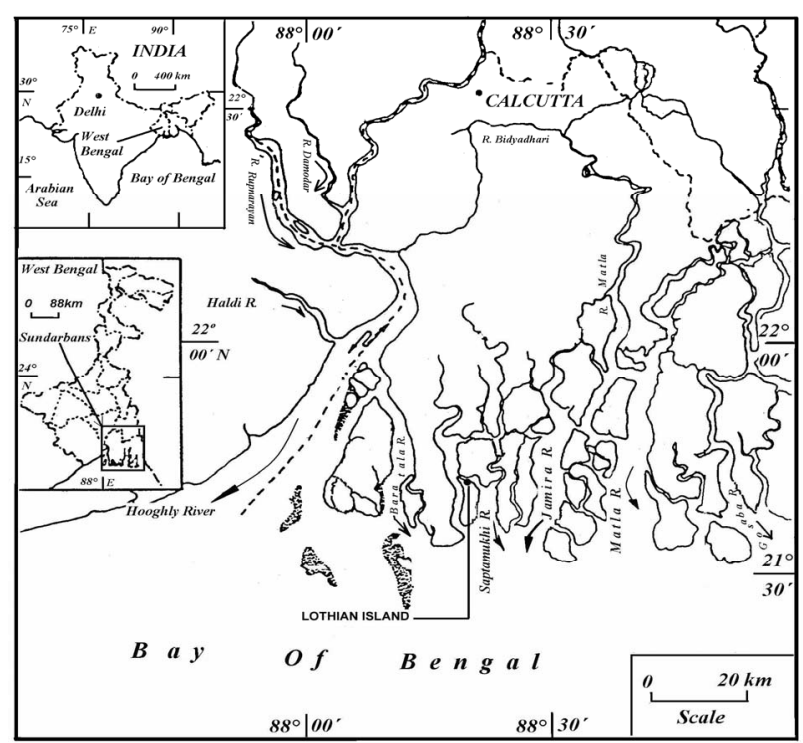

Figure 1. The map is showing the study area.

stored at $4^{\circ} \mathrm{C}$ immediately after collection and transported with adequate care to the laboratory for analysis. For quantification of different types of bacteria we followed the procedure as described by Ramnathan et al.; 2008 [12]. We homogenized $10 \mathrm{gm}$ of the samples collected from different locations in sterile phosphate buffer solution. Serial dilutions up to $10^{-4}$ were made and inoculation was done with $0.1 \mathrm{ml}$ homogenized sample. For quantification of free-living Nitrogen fixers, inoculations from each zone were done in a selective medium, comprising Mannitol (15.0 gms), $\mathrm{K}_{2} \mathrm{HPO}_{4}$ (0.5 gms), $\mathrm{MgSO}_{4} \cdot 7 \mathrm{H}_{2} \mathrm{O}$ (0.2 gms), $\mathrm{CaSO}_{4}$ (0.1 gms), $\mathrm{NaCl}$ (0.2 gms), $\mathrm{CaCO}_{3}$ (5.0 gms), Agar (15.0 gms), Isotonic solution with the soil was prepared with $\mathrm{NaCl}$ and sterilized distilled water (1lt) and pH maintained at 8.3. Phosphate solubilizing bacteria (PSB) were enumerated using Pikovskaya's medium that had the following composition: Glucose (10 gm), $\mathrm{Ca}_{3}\left(\mathrm{PO}_{4}\right)_{2}(5 \mathrm{gm}),\left(\mathrm{NH}_{4}\right)_{2} \mathrm{SO}_{4}(0.5 \mathrm{gm}), \mathrm{KCl}$ (0.2 gm), Agar (20 gm), Isotonic solution with the soil was prepared with $\mathrm{NaCl}$ and sterilized distilled water (1lt) and $\mathrm{pH}$ maintained at (6.8 - 7.0). Cellulose decomposing bacteria (CDB) were isolated and quantified in selective media containing $\mathrm{K}_{2} \mathrm{HPO}_{4}$ (1.0 gms), $\mathrm{CaCl}_{2}$ (0.1 gms), $\mathrm{MgSO}_{4} \cdot 7 \mathrm{H}_{2} \mathrm{O}$ (0.2 gms), $\mathrm{NaCl}$ (0.1 gms), $\mathrm{FeCl}_{3}(0.02$ gms), $\mathrm{NaNO}_{3}$ (2.0 gms), Agar (12.0 gms). Precipitated cellulose (4.0 gms), Isotonic solution with the soil was prepared with $\mathrm{NaCl}$ and sterilized distilled water $\left(\begin{array}{ll}1 & \mathrm{lt}\end{array}\right)$. Fungi were enumerated in the Czapedox agar media, which contained $\mathrm{NaNO}_{3}$ (3.0 gm), $\mathrm{KH}_{2} \mathrm{PO}_{4}$ (1.0 gm), $\mathrm{MgSO}_{4} \cdot 7 \mathrm{H}_{2} \mathrm{O}(0.5 \mathrm{gm}), \mathrm{KCl}(0.5 \mathrm{gms}), \mathrm{FeSO} 4 \cdot 7 \mathrm{H}_{2} \mathrm{O}$ (0.01 gms), Sucrose (30 gms), Agar (15 gms), $\mathrm{ZnSO}_{4} \cdot 7 \mathrm{H}_{2} \mathrm{O}$ ( $0.05 \mathrm{gms})$, Isotonic solution with the soil prepared from $\mathrm{NaCl}$ and sterilized distilled water (1 $1 \mathrm{tr})$ [12]. The nitrifying bacteria were quantified on Winogardsky's me- 
$\operatorname{dium}\left(\mathrm{g} / \mathrm{l}: \mathrm{K}_{2} \mathrm{HPO}_{4} 1, \mathrm{NaCl} 2, \mathrm{MgSO}_{4} \cdot 7 \mathrm{H}_{2} \mathrm{O} 0.5, \mathrm{FeSO}_{4} \cdot 7 \mathrm{H}_{2} \mathrm{O}\right.$ trace, $\mathrm{CaCl}_{2} \cdot 2 \mathrm{H}_{2} \mathrm{O} 0.02, \mathrm{pH} 8.5$ ) containing $1.0 \mathrm{~g} / 1$ either $\left(\mathrm{NH}_{4}\right)_{2} \mathrm{SO}_{4}$ and the colonies were visualized (pinkish hue) by flooding the plates with sulphanillic acid reagent (sulphanillic acid $8 \mathrm{~g} / \mathrm{l}$ acetic acid $(5 \mathrm{M})$ and $\alpha$-naphthayl amine $5 \mathrm{~g} / \mathrm{l}$ acetic acid $(5 \mathrm{M}) ; 1: 1, \mathrm{v} / \mathrm{v})$ [13]. Sulfate reducing bacteria (SRB) were cultured under anaerobic condition for quantification in Starkey's medium containing $\mathrm{K}_{2} \mathrm{HPO}_{4}, 0.5$ gm; $\mathrm{NH}_{4} \mathrm{Cl}, 1$ gm; $\mathrm{Na}_{2} \mathrm{SO}_{4}$, $1 \mathrm{gm} ; \mathrm{CaCl}_{2} \cdot 2 \mathrm{H}_{2} \mathrm{O}, 0.1 \mathrm{gm} ; \mathrm{MgSO}_{4} \cdot 7 \mathrm{H}_{2} \mathrm{O}, 2 \mathrm{gm}$; Sodium Lactate $\left(70 \%\right.$ Solution), $5 \mathrm{gm} ; \mathrm{FeSO}_{4} \cdot\left(\mathrm{NH}_{4}\right)_{2} \mathrm{SO}_{4} \cdot 6 \mathrm{H}_{2} \mathrm{O}$, $0.5 \mathrm{gm}$; Isotonic solution with the soil prepared from $\mathrm{NaCl}$ and sterilized distilled water $(1 \mathrm{~L})$ and $\mathrm{pH}$ maintained at (7.0 - 7.5) [14].

\subsection{Sediment Quality Measurement}

Concentrations of Sulphate-Sulphur, Nitrate-Nitrogen, Nitrite-Nitrogen, Phosphate-Phosphorous, and SilicateSilica in the soil sediment sample were measured following standard procedure $[15,16]$. The $\mathrm{pH}$ value was measured in a 1:5 (w/w) soil water suspension using an electric digital $\mathrm{pH}$ meter [17] and salinity of a soil saturation extract (ECe) was determined by measuring the electrical conductance of soil water saturation extract with the help of a conductivity meter [18]. Soil organic carbon was measured by standard methods [19]. Soil redox potentials (Eh) at each sampling site were measured with brightened platinum electrodes which were allowed to equilibrate in situ for $1 \mathrm{hr}$ prior to measurement. Each electrode was checked before using the quinhydrone in $\mathrm{pH} 4$ and 7 buffers ( $\mathrm{mV}$ reading for quinhydrone is 218 and 40.8 , respectively, at $25^{\circ} \mathrm{C}$ ). The potential of a calomel reference electrode $(+244 \mathrm{mV})$ was added to each value to calculate $\mathrm{Eh}$ value for the sediment samples [20].

\subsection{Measurement of Enzyme Activity}

Dehydrogenase activity assay: Moist 1 gm soil sample from each depth was mixed with $1.5 \mathrm{ml}$ TRIS buffer and $2 \mathrm{ml} 0.5 \%$ aqueous solution of iodonitrotetrazolium chloride (substrate). After $2 \mathrm{hr}$ of incubation, the samples were extracted by using $10 \mathrm{ml}$ solution N,N-dimethylformamide/ethanol in a 1:1 ratio. Produced iodonitro tetrazolium formazan (INTF) were measured immediately spectrophotometrically at $464 \mathrm{~nm}$ [21]. Determination of $\beta$-D-Glucosidase activity: $1 \mathrm{gm}$ of the collected soil samples from different depth region were mixed with acetate buffer. After 10min, p-nitrophenyl- $\beta$-Dglucopyranoside (substrate) was added in required amount and incubated at $37^{\circ} \mathrm{C}$ temperature for 1 hour. Ethanol (95\%) was added in required amount to terminate the reaction. Released para nitro phenol (PNP) was determined spectrophotometrically at $400 \mathrm{~nm}[22]$.

\section{RESULT AND DISCUSSION}

Table 1 depicts the seasonal variations of total microbial populations, organic carbon content and physico-che-

Table 1. Seasonal variations of physico-chemical parameters and microbial population (CFU $\times 10^{6} \cdot \mathrm{g}^{-1}$ dry sediment) at different depth in Sundarban mangrove environment.

\begin{tabular}{|c|c|c|c|c|c|c|c|c|c|c|c|}
\hline Season & Depth $(\mathrm{cm})$ & $\mathrm{Eh}(\mathrm{mV})$ & $\mathrm{pH}$ & Temp $\left({ }^{\circ} \mathrm{C}\right)$ & Salinity (PSU) & Org.C & $\mathrm{SO}_{4}^{-2}$ & $\mathrm{PO}_{4}^{-3}$ & $\mathrm{NO}_{3}^{-}$ & $\mathrm{NO}_{2}^{-}$ & $\mathrm{CFU} \times 10^{6}$ \\
\hline \multirow{7}{*}{ Pre-mon-soon } & 0 & -98 & 7.94 & 17.83 & 16.97 & 1.03 & 1.83 & 0.315 & 0.175 & 0.049 & 12.237 \\
\hline & 10 & -102 & 8.39 & 17.83 & 17.01 & 0.97 & 1.64 & 0.305 & 0.179 & 0.048 & 11.604 \\
\hline & 20 & -108 & 8.27 & 17.82 & 17.08 & 0.92 & 1.42 & 0.315 & 0.166 & 0.045 & 10.62 \\
\hline & 30 & -112 & 8.23 & 17.82 & 17.23 & 0.82 & 1.38 & 0.340 & 0.221 & 0.044 & 9.279 \\
\hline & 40 & -128 & 8.25 & 17.82 & 17.35 & 0.78 & 1.29 & 0.321 & 0.245 & 0.048 & 8.560 \\
\hline & 50 & -136 & 8.21 & 17.80 & 17.84 & 0.75 & 1.21 & 0.285 & 0.226 & 0.032 & 8.941 \\
\hline & 60 & -143 & 8.19 & 17.82 & 17.87 & 0.70 & 1.07 & 0.239 & 0.214 & 0.050 & 7.763 \\
\hline \multirow{7}{*}{ Mon-soon } & 0 & -102 & 8.22 & 24.68 & 14.99 & 0.87 & 1.04 & 0.320 & 0.204 & 0.047 & 11.547 \\
\hline & 10 & -112 & 8.12 & 24.71 & 15.05 & 0.82 & 1.00 & 0.262 & 0.183 & 0.045 & 10.326 \\
\hline & 20 & -135 & 8.19 & 24.67 & 15.05 & 0.80 & 0.89 & 0.280 & 0.173 & 0.044 & 10.103 \\
\hline & 30 & -148 & 8.18 & 24.69 & 15.17 & 0.83 & 0.91 & 0.230 & 0.159 & 0.047 & 8.921 \\
\hline & 40 & -165 & 8.14 & 24.59 & 15.22 & 0.70 & 0.82 & 0.250 & 0.159 & 0.058 & 7.767 \\
\hline & 50 & -173 & 8.16 & 23.82 & 15.28 & 0.67 & 0.94 & 0.210 & 0.163 & 0.048 & 7.413 \\
\hline & 60 & -175 & 8.12 & 23.73 & 15.41 & 0.59 & 0.87 & 0.190 & 0.162 & 0.048 & 6.396 \\
\hline \multirow{7}{*}{ Post-mon-soon } & 0 & -121 & 8.42 & 12.94 & 15.35 & 1.37 & 1.31 & 0.675 & 0.205 & 0.024 & 13.529 \\
\hline & 10 & -128 & 8.37 & 12.95 & 15.36 & 1.26 & 1.20 & 0.612 & 0.197 & 0.014 & 12.183 \\
\hline & 20 & -131 & 8.34 & 12.94 & 15.46 & 1.25 & 1.13 & 0.566 & 0.171 & 0.013 & 10.958 \\
\hline & 30 & -135 & 8.32 & 12.93 & 15.53 & 1.07 & 1.14 & 0.511 & 0.176 & 0.021 & 10.743 \\
\hline & 40 & -145 & 8.24 & 12.90 & 15.55 & 0.97 & 1.06 & 0.441 & 0.151 & 0.021 & 9.576 \\
\hline & 50 & -167 & 8.24 & 12.92 & 15.67 & 0.92 & 1.06 & 0.443 & 0.136 & 0.019 & 9.008 \\
\hline & 60 & -187 & 8.19 & 13.12 & 15.69 & 0.93 & 0.94 & 0.344 & 0.130 & 0.018 & 8.003 \\
\hline
\end{tabular}


mical parameters at various depths in Sundarban mangrove sediment. Temperature and Eh values of soil samples showed a decreasing trend from surface to a depth of 60 $\mathrm{cm}$. A reverse profile was observed in case of $\mathrm{pH}$ and salinity. During monsoon, the salinity was found to be $14.99 \mathrm{psu}$ in surface soil and it was $15.41 \mathrm{psu}$ at $60 \mathrm{~cm}$ below surface. Less soil salinity in monsoon with respect to pre-monsoon and post-monsoon may be due to high degree of dilution by river (freshwater) run off during monsoon period [23]. Eh value showed a decreasing trend from surface soil $(-98 \mathrm{mV})$ to the $60 \mathrm{~cm}$ depth $(-143 \mathrm{mV})$ which represented more anoxicity of bottom soil than that of surface during pre-monsoon (Table 1). Soil redox potential value (Eh) from surface to a region of $60 \mathrm{~cm}$ of depth in three distinct seasons suggested that the soil of deep forest region of Sundarban Mangrove is relatively anoxic or it can be referred to as oxygen-impoverished or oxygen-starved soil.

Total number of microbial populations in surface soil was found to be $12.237 \times 10^{6}, 11.547 \times 10^{6}$ and $13.529 \times$ $10^{6}$ (C.F.U g ${ }^{-1}$ dry wt. of sediment) compared to $7.763 \times$ $10^{6}, 6.396 \times 10^{6} \& 8.003 \times 10^{6}$ (C.F.U g ${ }^{-1}$ dry wt. of sediment) at the $60 \mathrm{~cm}$ depth during pre-monsoon, monsoon and post-monsoon respectively (Table $\mathbf{1}$ ).

Depth profile exploration with respect to microbial population showed an inverse relationship between the total bacterial population and depth $(\mathrm{cm})$ (Figure 2) [The regression equation is, Total bacterial population $=2.94187+7.55525$ Organic $\mathrm{C}(\%) ; \mathrm{F}=42.86 ; \mathrm{P}=$ $0.000 ; \mathrm{n}=21$ ] whereas a direct relationship is reflected from the study between the total bacterial population and organic $\mathrm{C} \%$ throughout the year (Figure 3). [The regression equation is Total bacterial population $=12.2396-$ 0.0818286 Depth (cm); F = 91.74; $\mathrm{P}=0.000 ; \mathrm{n}=21$ ].

During three seasons, the decrease in total microbial population with increasing depth might be due to depletion of organic carbon with increase in depth since previous studies have revealed that organic carbon is most significant for controlling microbial population

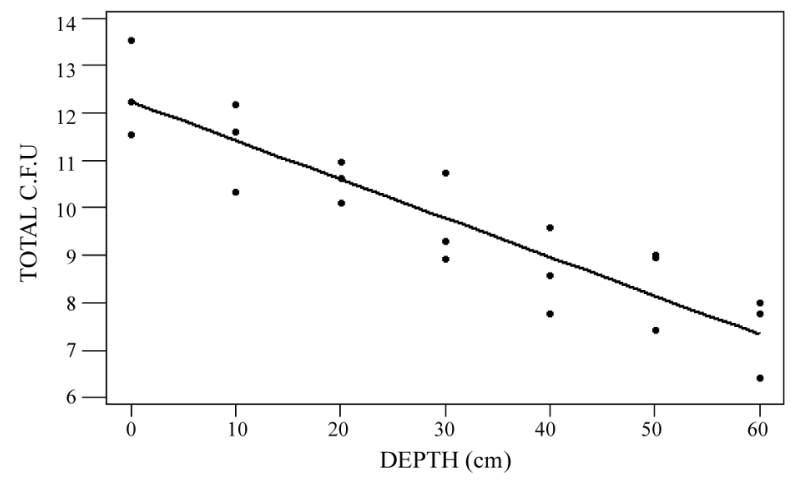

Figure 2. Relationship between Total CFUs $\left(\times 10^{6}\right)$ and depth (cm).

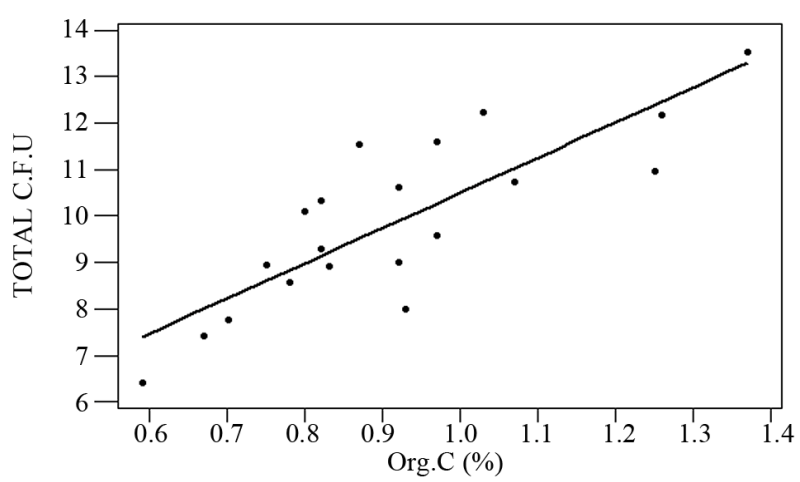

Figure 3. Relationship between Total CFUs $\left(\times 10^{6}\right)$ and organic carbon.

[24]. Decrease in Nitrate-Nitrogen concentration with increase in depth (Table 1) could be explained by the decrease in population of nitrifying bacteria with increase in depth as earlier study has showed active participation of nitrifying bacteria in bio-mineralization [25]. The concentration of phosphate-phosphorous was found to be 0.675 and $0.344 \mu \mathrm{g} \cdot \mathrm{g}^{-1}$ dry wt. of sediment in surface and at a depth of $60 \mathrm{~cm}$ respectively, during postmon-soon. The concentration of Phosphate-Phosphorous, Sulfate-Sulfur, organic Carbon and organic matter were found to show a decreasing trend with increase in depth. Dehydrogenase activity plays an essential role in the initial stages of oxidation of soil organic matter [11]. Dehydrogenase activity was found to diminish from surface with increase in depth (Figure 4) and the regression equation is Dehydrogenase $=373.563-1.57281$ Depth $(\mathrm{cm}) ;[\mathrm{F}=2.80548, \mathrm{P}=0.110, \mathrm{n}=21]$.

During pre-monsoon, the depth profile study with respect to enzyme activity evoked an informative scenario. Dehydrogenase and $\beta$-D glucosidase activity were found to show a decreasing trend with increase in depth (Figure 5(a)). Dehydrogenase activity was found to show decreasing trend with increasing depth. Same profile was found for $\beta$-D glucosidase activity (Figure 5(b)). Niemi

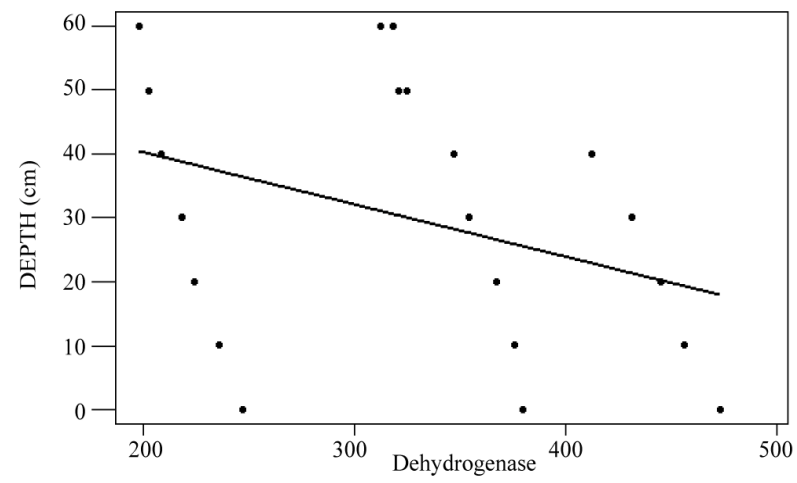

Figure 4. Relationship between enzyme (dehydrogenase) activity and depth $(\mathrm{cm})$. 
R.M. et al. in 2005 [26] showed similar trend of enzyme activity with increase in depth. During post monsoon urease activity did not show significant gradation with increasing depth from surface to $60 \mathrm{~cm}$ of depth. Both dehydrogenase and $\beta$-D glucosidase activity were found

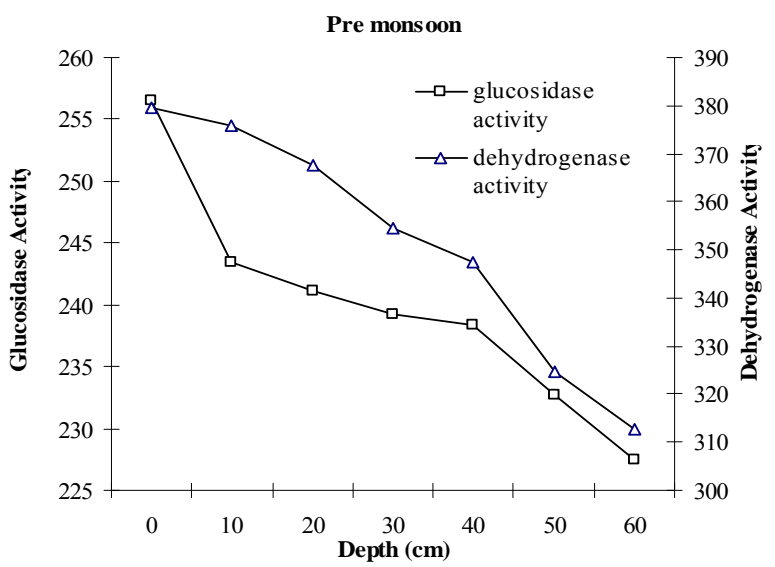

(a)

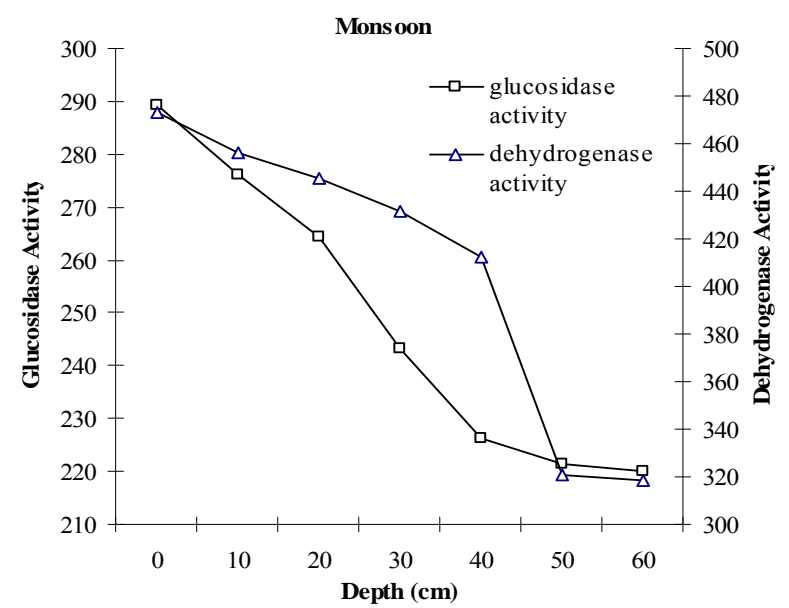

(b)

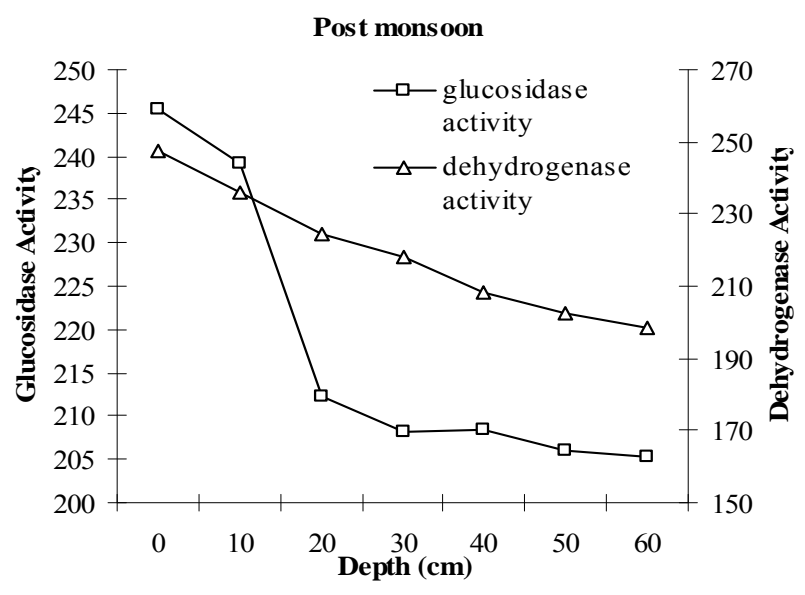

(c)

Figure 5. Depth profile of soil enzyme activity during premonsoon, (a) monsoon and (b) post monsoon(c). to show decreasing pattern with increase in depth up to $20 \mathrm{~cm}$ of depth (Figure 5(c)).

Culture methods used in this study to assess the seasonal influences on the microbial community of the Sundarban mangrove forest ecosystem detected six different types of microbes (Cellulose Decomposing Bacteria, Sulfate Reducing Bacteria, Phosphate Solubilizing Bacteria, Nitrogen Fixing Bacteria, Fungi, and Nitrifying Bacteria). Apart from these six different types (Proteobacteria, Flexibacteria, Actinobacteria, Chloflexi, Plantomycetes, and Gammatimonadates) were detected. Ghosh et al. 2010 [27] detected two more types (Acidobacteria, Firmicutes), using culture independent method in the Sundarban mangrove sediment. Plate culture method is able to count only a fraction of total microbial load accessible in soil; however they provide a valid and reliable measure of heterotrophic microbial biomass and activities present in the soil and generally the variations in number of colony forming units correspond to the variations in the total microbial community [28-30]. From the season wise study of relative abundance of microbial population of different category, an expounding outcome was revealed. During pre-monsoon the most dominating group was cellulose decomposing bacteria (40\%). Least dominance was showed by free living nitrogen fixing bacteria (5\%). Phosphate solubilizing bacteria (8\%), Sulfate reducing bacteria (9\%) and nitrifying bacteria (15\%), however, showed considerable relative abundance (Figure 6(a)). During monsoon, the most dominating group was cellulose decomposing bacteria (49\%) prior to fungi (21\%). Least supremacy was exhibited by free living nitrogen fixing bacteria (4\%). Phosphate solubilizing bacteria (10\%), Sulfate reducing bacteria (4\%) and nitrifying bacteria $(12 \%)$ showed considerable relative abundance (Figure 6(b)).

Climatic condition and occurrence of plenty of organic carbon in the soil throughout the year might be responsible for maximum abundance of cellulose decomposing bacteria [31]. The post monsoon season also followed the same pattern with the most dominating group of microbe being cellulose decomposing bacteria (47\%) prior to fungi $(21 \%)$. Free living Nitrogen fixing bacteria was of least dominance (5\%).

Phosphate solubilizing bacteria $(10 \%)$, Sulfate reducing bacteria $(5 \%)$ and nitrifying bacteria (12\%) following the pattern reflected earlier showed quite considerable relative abundance (Figure 6(c)).

Increase in population of sulfate reducing bacteria with increase in depth might be due to increase in anoxicity with increase in depth [32]. Twelve parameters viz. Total C.F.U, pH, Eh (mV) , Temp $\left({ }^{\circ} \mathrm{C}\right)$, Salinity (psu), $\mathrm{NO}_{3}^{-}, \mathrm{NO}_{2}^{-}$, Organic $\mathrm{C} \%, \mathrm{PO}_{4}^{-3}, \mathrm{SO}_{4}^{-2}$, glucosidase activity and dehydrogenase activity were included in the PCA (principal component analysis). 


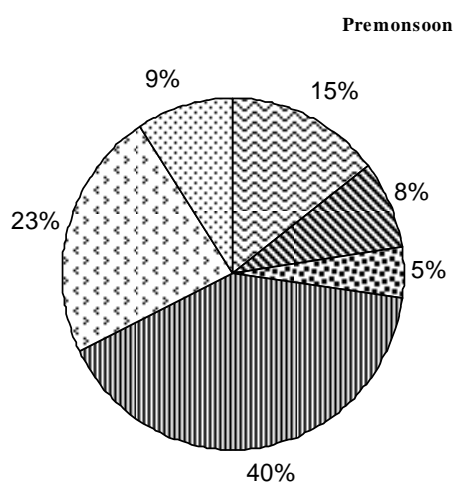

Ð Nitrifying Bacteria

(a)

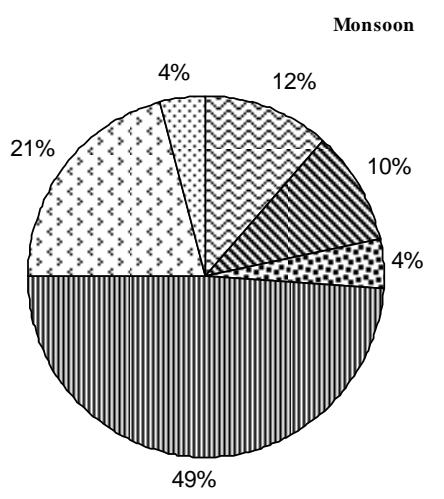

$\nabla$ Nitrifying Bacteria

\$ Phosphate Solubilizing Bacteria

Free Living Nitrogen Fixing Bacteria

血 Cellulose Decomposing Bacteria

$\square$ Fungi

母ulfate Reducing Bacteria

(b)

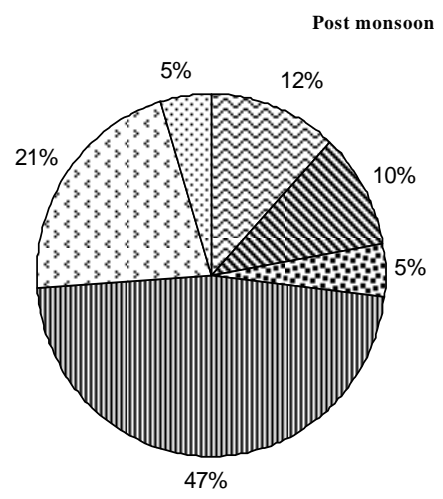

Q Nitrifying Bacteria

\$ Phosphate Solubilizing Bacteria

G Free Living Nitrogen Fixing Bacteria

[I Cellulose Decomposing Bacteria

๑ Fungi

‥ Sulfate Reducing Bacteria
Table 2. Principal Component Analysis (Eigenanalysis of the Correlation Matrix): Total C.F.U, pH, Temp $\left({ }^{\circ} \mathrm{C}\right)$, Eh $(\mathrm{mV})$, Salinity (psu), $\mathrm{NO}_{3}^{-}\left(\mu \mathrm{g} \cdot \mathrm{g}^{-1}\right.$ dry wt of soil), $\mathrm{NO}_{2}^{-}\left(\mu \mathrm{g} \cdot \mathrm{g}^{-1}\right.$ dry wt of soil), Organic $\mathrm{C} \%, \mathrm{PO}_{4}^{-3}\left(\mu \mathrm{g} \cdot \mathrm{g}^{-1}\right.$ dry wt of soil $), \mathrm{SO}_{4}^{-2}$ $\left(\mathrm{mg} \cdot \mathrm{g}^{-1}\right.$ dry wt of soil ), $\beta$-D Glucosidase activity ( $\mu \mathrm{g}$ PNP produced $\mathrm{hr}^{-1} \cdot \mathrm{g}^{-1}$ dry wt of soil) \& dehydrogenase activity [nmol INTF (g dry wt of soil $)^{-1} 2 \mathrm{~h}^{-1}$ ].

\begin{tabular}{ccccccc}
\hline Eigen value & 5.0444 & 3.5581 & 1.7686 & 0.8810 & 0.3800 & 0.1591 \\
\hline Proportion & 0.420 & 0.297 & 0.147 & 0.073 & 0.032 & 0.013 \\
Cumulative & 0.420 & 0.717 & 0.864 & 0.938 & 0.969 & 0.983 \\
Variable & PC1 & PC2 & PC3 & PC4 & PC5 & PC6 \\
Total CFU & 0.265 & -0.367 & -0.268 & 0.172 & 0.020 & 0.006 \\
pH & 0.314 & -0.049 & -0.045 & -0.571 & 0.724 & -0.113 \\
Eh (mV) & 0.061 & -0.508 & -0.032 & 0.076 & 0.067 & -0.258 \\
Temp & -0.407 & -0.060 & -0.261 & -0.106 & 0.094 & 0.162 \\
Salinity & -0.023 & -0.199 & 0.682 & 0.008 & 0.058 & -0.298 \\
$\mathrm{NO}_{3}^{-}$ & -0.015 & -0.343 & 0.274 & -0.629 & -0.469 & 0.277 \\
$\mathrm{NO}_{2}^{-}$ & -0.390 & -0.175 & 0.072 & 0.025 & 0.315 & 0.626 \\
Org.C $^{-3}$ & 0.401 & -0.140 & -0.204 & 0.124 & -0.036 & 0.235 \\
$\mathrm{PO}_{4}^{-3}$ & 0.423 & -0.042 & -0.148 & -0.116 & -0.187 & 0.315 \\
$\mathrm{SO}_{4}^{-2}$ & 0.142 & -0.378 & 0.312 & 0.443 & 0.189 & 0.257 \\
$\beta$-D Glucosidase & -0.171 & -0.412 & -0.323 & -0.069 & -0.213 & -0.323 \\
Dehydrogenase & -0.347 & -0.282 & -0.213 & -0.033 & 0.146 & -0.109 \\
\hline & & & & & &
\end{tabular}

tively correlated with total bacterial populations.

\section{CONCLUSIONS}

From the present study an efficient conclusion can be drawn as a result of our research on depth profile exploration of enzyme activity with microbial community from the oxygen-starved soil of Sundarban Mangrove forest, India. Organic carbon from the leaves, wood from forest and other organic dead or waste products from other living organisms are easily degraded by cellulose decomposing bacteria in the mangrove sediment because they are the most dominating group of microbes prior to fungi. Other groups of microbes have also exhibited significant population count which helps in bio-mineralizetion. Microbial activity throughout the year with respect to dehydrogenase activity and $\beta$-D glucosidase activity were found to be efficient enough to carry out active bio-mineralization through biogeochemical cycles. Vertical decrease in nutrient concentration along with soil enzyme activity suggested that increasing depth caused unfavorable condition for microorganisms to carry out bio-mineralization processes.

\section{ACKNOWLEDGEMENTS}

The financial assistance from DOEn, Govt. of West Bengal and U. G. C., New Delhi are gratefully acknowledged. The authors are also grateful to the Forest Department, Govt. of West Bengal for assisting 
the research team in collecting data and providing all infrastructural facilities to reach the remote island.

\section{REFERENCES}

[1] Gonzalez-Acosta, B., Bashan, Y., Hernandez-Saavedra, N.Y., Ascenaio, F. and Cruz-Aguero, G. (2006) Seasonal seawater temperature as the major determinant for populations of culturable bacteria in the sediments of an intact mangrove in an arid region. FEMS Microbiology Ecology, 55, 311-321. doi:10.1111/j.1574-6941.2005.00019.x

[2] Alongi, D.M., Boto, K.G. and Tirendi, F. (1989) Effect of exported mangrove litter on bacterial productivity and dissolved organic carbon fluxes in adjacent tropical nearshore sediments. Marine Ecology Progress Series, 56, 133144. doi: $10.3354 / \operatorname{meps} 056133$

[3] Alongi, D.M., Christofferson, P. and Tirendi, F. (1993) The influence of forest type on microbial-nutrient relationship in tropical mangrove sediment. Journal of Experimental Marine Biology and Ecology, 171, 201-223. doi:10.1016/0022-0981(93)90004-8

[4] Alongi, D.M. (1994) The role of bacteria in nutrient recycling in tropical mangrove and other coastal benthic ecosystems. Hydrobiologia, 285, 19-32. doi:10.1007/BF00005650

[5] Holguin, G., Bashan, Y. and Vazavez, P. (2001) The role of sediment microorganism in the productivity, conservation and rehabilitation of mangrove ecosystem: An Overview. Biology of Fertile Soils, 33, 265-278. doi:10.1007/s003740000319

[6] Vazquez, P., Holguin, G., Puente, M.E., Lopez-Cortes, A. and Bashan, Y. (2000) Phosphate-solubilizing microorganisms associated with the rhizosphere of mangroves in a semiarid coastal lagoon. Biology and Fertility of Soils, 30, 460-468. doi:10.1007/s003740050024

[7] Rojas, A., Holguin, G., Glick, B.R. and Bashan, Y. (2001) Synergism between Phyllobacterium sp. ( $\mathrm{N}_{2}$-fixer) and Bacillus licheniformis (P-solubilizer), both from a semiarid mangrove rhizosphere. FEMS Microbiology Ecology, 35, 181-187. doi:10.1111/j.1574-6941.2001.tb00802.x

[8] Teri, C.B. and Mary, K.F. (2005) Linking microbial community composition and soil processes in a California annual grassland and mixed conifer forest. Biogeochemistry, 73, 395-415. doi:10.1111/j.1574-6941.2001.tb00802.x

[9] Riley, R.H., Peter, M. and Vitousek, P.M. (1995) Nutrient dynamics and nitrogen trace gas flux during ecosystem development in montane rain forest. Ecology, 76, 292304. doi: $10.2307 / 1940650$

[10] Wlodarczyk, T., (2000) $\mathrm{N}_{2} \mathrm{O}$ emission and absorption against a background of $\mathrm{CO}_{2}$ in Eutric Cambisol under different oxidation-reduction conditions. Acta Agrophysica, 28, 39-43.

[11] Pascual, J.A., Hernandez, T., Garcia, C. and Ayuso, M. (1998) Enzymatic activities in an arid soil amended with urban organic wastes: Laboratory experiment. Bioresource Technology, 64, 131-138. doi:10.1016/S0960-8524(97)00171-5

[12] Ramanathan, A.L., Singh, G., Majumder, J., Samal, A.C., Chowhan, R., Rayan, R.K., Roykumar, K. and Santra, S.C. (2008) A study of microbial diversity and its interaction with nutrients in the sediments of Sundarban man- groves. Indian Journal of Marine Science, 37, 159-165.

[13] Das, J. and Dangar, T.K. (2008) Microbial population dynamics, especially stress tolerant Bacillus thuringiensis, in partially anaerobic rice field soils during postharvest period of the Himalayan, island, brackish water and coastal habitats of India. World Journal of Microbiology and Biotechnology, 24, 1403-1410.

[14] Sahrani, F.K., Ibrahim, Z., Yahya, A. and Aziz, M. (2008) Isolation and Identification of Marine Sulfate Reducing Bacteria Desulfovibrio sp and Citrobacter freundii from Pasir Gudang, Malaysia. Sains Malyasiana, 37, 365-371.

[15] Grasshoff, K., Ehrhardt, M. and Kremling, K. (1983) Standard method for sea water analysis. 2nd Edition, Wiley-VCH, Weinheim.

[16] Mussa, S.A.B., Elferjani, H.S., Haroun, F.A. and Abdelnabi, F.F. (2009) Determination of available nitrate, phosphate and sulfate in soil samples. International Journal of Pharm Tech Research, 1, pp 598-604.

[17] Tiwari, S.C., Tiwari, B.K. and Mishra, R.R (1989) Microbial community, enzyme activity and $\mathrm{CO}_{2}$ evolution in Pineapple Orchard soil. Tropical Ecology, 30, 265-273.

[18] Richards, L.A. (Ed.) (1968) Diagnosis and improvement of Saline and Alkali soils. Oxford and IBH Publishing Co., New Delhi, 160.

[19] Walkley, A. and Black, I.A. (1934) An examination of Degtjareff method for determining soil organic matter, and a proposed modification of the chromic acid titration method. Soil Science, 37, 29-38. doi:10.1097/00010694-193401000-00003

[20] Mckee, K.L., Mendelssohn, I.A. and Hester, M.W. (1988) Reexamination of pore water Sulfhde concentrations and Redox Potentials near the aerial roots of Rhizophora Mangle and Avicennia Germinans. American Journal of Botany, 75, 1352-1359. doi:10.2307/2444458

[21] Mersi, W. and Schinner, F. (1991) An improved and accurate method for determiningthe dehydrogenase activity of soils with iodonitrotetrazolium chloride. Biology and Fertility of Soils, 11, 216-220. doi:10.1007/BF00335770

[22] Knight, T.R. and Dick, R.P. (2004) Differentiating microbial and stabilized b-glucosidase activity relative to soil quality. Soil Biology \& Biochemistry, 36, 2089-2096. doi:10.1016/j.soilbio.2004.06.007

[23] Wahid, S.M., Babel, M.S. and Bhuiyan, A.R. (2007) Hydrologic monitoring and analysis in the Sundarbans mangrove ecosystem, Bangladesh. Journal of Hydrology, 332, 381-395. doi:10.1016/j.jhydrol.2006.07.016

[24] Kirchman, D.L and Rich, J.H. (1997) Regulation of Bacterial Growth Rates by Dissolved Organic Carbon and Temperature in the Equatorial Pacific Ocean. Microbial Ecology, 33, 11-20.

[25] Ward, B.B. (1996) Nitrification and denitrification: Probing the nitrogen cycle in aquatic environments. Microbial Ecology, 32, 247-261. doi:10.1007/BF00183061

[26] Niemi, R.M., Vepsäläinen, M., Wallenius, K., Simpanen, S., Alakukku, L. and Pietola, L. (2005) Temporal and soil depth-related variation in soil enzyme activities and in root growth of red clover (Trifolium pratense) and timothy (Phleum pratense) in the field. Applied Soil Ecology, 30, 113-125. doi:10.1016/j.apsoil.2005.02.003

[27] Ghosh, A., Dey, N., Bera, A., Tiwari, A., Sathyniranjan, K.B., Chakrabarti, K. and Chattopadhyay, D. (2010) Culture independent molecular analysis of bacterial commu- 
nities in the mangrove sediment of Sunderban, India. Saline Systems, 6, 1-11. doi:10.1186/1746-1448-6-1

[28] Tiwari, S.C., Tiwari, B.K. and Mishra, R.R. (1986) Temporal and depth-wise variations in $\mathrm{CO}_{2}$ evolution and microbial population in pineapple plantation soil. Journal of Soil Biology and Ecology, 6, 67-76.

[29] Tiwari, S.C., Tiwari, B.K. and Mishra, R.R. (1987) The influence of moisture regimes on the population of activity of soil microorganisms. Plant and Soil, 101, 133-136. doi:10.1007/BF02371041

[30] Tiwari, S.C., Tiwari, B.K. and Mishra, R.R. (1987) Temporal and depth-wise variations in dehydrogenase and urease activities and bacterial population in pineapple plantation soils. Proceedings of Indian National science Academy Part B, 53, 173-176.

[31] Ashokkumar, S., Rajaram, G., Manivasagan, P., Ramesh, S., Sampathkumar, P. and Mayavu, P. (2010) Studies on hydrographical parameters, nutrients and microbial populations of mullipallam creek in muthupettai mangroves (southeast coast of India). Research Journal of Microbiology, 6, 71-86.

[32] Hakansson, T., Suer, P., Mattiasson, B. and Allard, B. (2008) Sulphate reducing bacteria to precipitate mercury after electrokinetic soil remediation. International Journal of Environmental Science and Technology, 5, 267274. 